\title{
A method of decontaminating Strongyloides venezuelensis larvae for the study of strongyloidiasis in germ-free and conventional mice
}

\author{
W. A. MARTINS*†, A. L. MELO†, J. R. NICOLI*, D. C. CARA:, M. A. R. CARVALHO*, \\ M. A. LANA*, E. C. VIEIRA $\S$ and L. M. FARIAS* \\ * Departamento de Microbiologia, †Departamento de Parasitologia, †Departamento de Patologia and \\ $\S$ Departamento de Bioquímica-Imunologia, Instituto de Ciências Biológicas, Universidade Federal de Minas \\ Gerais, CP 486, 30161-970 Belo Horizonte MG, Brazil
}

To study the possible influence of intestinal micro-organisms on the course of strongyloidiasis in mice, a method was developed to obtain axenic infective larvae of Strongyloides venezuelensis. Cultured larvae from conventional mice were treated with sodium hypochlorite $0.25 \%$ for $10 \mathrm{~min}$, washed in distilled water and then exposed to various combinations of antibiotics for 30 or $60 \mathrm{~min}$. Success was achieved with a combination of penicillin $180 \mathrm{mg} / \mathrm{L}$ and ceftazidime $1 \mathrm{mg} / \mathrm{ml}$. Decontamination of the larvae was determined by aerobic and anaerobic culture and by inoculation into gnotobiotic mice. Viability was established by subcutaneous inoculation of larvae into germ-free and conventional mice. Preliminary results showed that gnotobiotic mice were more susceptible than conventional mice to infection with axenic $S$. venezuelensis larvae as judged by faecal egg excretion, recovery of worms in the small intestine and histopathological examination of the duodenal mucosa. These results suggest that the normal intestinal flora protects the host against experimental infection with $S$. venezuelensis.

\section{Introduction}

Strongyloides stercoralis is an important helminthic pathogen of man [1]. Infection is usually mild in immunocompetent individuals [2], but those with AIDS and other immune disorders may experience chronic, life-threatening and sometimes fatal infections [3]. Little is known about the interactions between $S$. stercoralis and the host at the mucosal surface, or the mechanism by which the severity of disease is altered in the immunocompromised host, especially those undergoing treatment with oral antibiotics that interfere with the normal intestinal flora. S. stercoralis does not infect mice or other laboratory animals, and $S$. venezuelensis is used as a model of strongyloidiasis $[1,4]$.

Received 5 July 1999; revised version accepted 15 Sept. 1999.

Corresponding author: Dr J.R. Nicoli (e.mail: jnicoli@mono. icb.ufmg.br).
The intestinal microflora influences the pathogenic effects of many protozoa, helminths and bacteria. However, studies in germ-free animals to establish these relationships require the use of axenic cultures of the infecting organism. Until now, viable and infectious worms of $S$. stercoralis or $S$. venezuelensis have not been obtained because of the sensitivity of these helminths to germicide treatments. This paper describes a method for obtaining axenic infective larvae of $S$. venezuelensis and reports preliminary findings on the influence of the normal microbial flora on the pathogenicity of the parasite.

\section{Materials and methods}

Mice

Conventional AKR/J mice were used for the maintenance of $S$. venezuelensis and for initial viability tests. Germ-free 50-day-old NIH mice (Taconic, Germantown, NY, USA) were used in the main part of the study. The animals were housed in flexible plastic isolators (Standard Safety Company, Pallatine, 
IL, USA) and handled according to established procedures [5]. Water and autoclavable diet (Nuvital, Curitiba, PA, Brazil) were steam-sterilised and administered ad libitum. Experiments with gnotobiotic mice were performed in micro-isolators (UNO Roestvaststaal, BV, Zevenaar, The Netherlands). Conventional $\mathrm{NIH}$ mice were derived from the germ-free colony and used only after at least two generations in conventional conditions. Conventional $\mathrm{AKR} / \mathrm{J}$ and $\mathrm{NIH}$ mice were maintained in an open animal house and fed the same diet as their germ-free counterparts.

\section{Parasite}

A S. venezuelensis strain isolated from wild rodents was maintained in the Laboratory of Invertebrate Taxonomy and Biology of the Parasitology Department (Federal University of Minas Gerais, Belo Horizonte, $\mathrm{MG}$, Brazil) by passage in $\mathrm{AKR} / \mathrm{J}$ mice.

\section{Disinfection}

Third-stage larvae (L3) of $S$. venezuelensis were recovered by a modification of the Baerman technique [6], by incubation ( 3 days at $27^{\circ} \mathrm{C}$ ) of faeces from infected AKR/J mice. The L3 larvae were first treated with sodium hypochlorite $0.25 \%$ for $10 \mathrm{~min}$, thoroughly washed with sterile distilled water, and then exposed to aqueous solutions of various antibiotics for 30 or $60 \mathrm{~min}$. Combinations of the following antibiotics were tested: benzylpenicillin $180 \mathrm{mg} / \mathrm{L}$, streptomycin $0.3 \mathrm{mg} / \mathrm{ml}$, ofloxacin $1.0 \mathrm{mg} / \mathrm{ml}$, gentamicin sulphate $100 \mathrm{mg} / \mathrm{ml}$, amikacin sulphate $1.0 \mathrm{mg} / \mathrm{ml}$, ceftazidime $1.0 \mathrm{mg} / \mathrm{ml}$. Finally, the larvae were thoroughly washed with sterile distilled water.

\section{Axenic status}

Treated larvae were placed inside tubes containing thioglycollate medium and brain heart infusion broth and incubated at $25^{\circ} \mathrm{C}$ and $37^{\circ} \mathrm{C}$ for 7 days. Freshly collected faeces from germ-free NIH mice before and after inoculation with decontaminated larvae were cultured in the same way.

\section{Viability and infectivity}

A $0.5-\mathrm{ml}$ suspension containing 500 decontaminated larvae was inoculated subcutaneously into each of five germ-free mice, five conventional NIH mice and two conventional AKR/J mice. Starting 3 days after infection, faeces from all mice were collected daily and examined to determine the beginning and the end of egg laying by the adult worm $[7,8]$. To determine the intensity of infection, freshly collected faeces from each mouse were weighed and broken up in a known volume of formalin $10 \%$ in centrifuge tubes. A measured volume of the faecal suspension was examined by microscopy. The eggs were counted and expressed as the number of eggs excreted per gram of faeces.

In a second experiment, similar groups of mice were used. Seven days after infection, the number of eggs in the faeces was determined and the mice were killed by ether inhalation. Worms were recovered by incubating longitudinally sliced small intestine of these animals in phosphate-buffered saline at $37^{\circ} \mathrm{C}$ for $5 \mathrm{~h}$. The worms were fixed in formalin $10 \%$ and counted. The faecal egg count:female worm count ratio for each animal was used to estimate fecundity. The length of the fixed worms was estimated by use of a camera lucida adapted to a stereomicroscope.

\section{Histopathological examination}

Paraffin-embedded histopathological sections of formalin-fixed mouse tissue were stained with haematoxylin and eosin. The slides were coded and examined by a pathologist, who was unaware of the experimental conditions of each group.

\section{Results}

\section{Decontamination of larvae}

Larvae remained viable after treatment with sodium hypochlorite, followed by benzylpenicillin in combination with streptomycin or ofloxacin, but complete decontamination was not achieved. In contrast, the combination of benzylpenicillin with amikacin or gentamicin totally decontaminated the larvae, but also killed them. Viable, axenic L3 larvae were obtained only by disinfection with sodium hypochlorite followed by exposure to a combination of benzylpenicillin $180 \mathrm{mg} / \mathrm{L}$ and ceftazidime $1.0 \mathrm{mg} / \mathrm{ml}$ for 30 or $60 \mathrm{~min}$.

\section{Experimental infection of germ-free and conventional mice}

Faecal egg counts of $S$. venezuelensis in germ-free mice experimentally infected with the axenic L3 larvae (obtained by the above method) were higher than those in conventional animals (Fig. 1). Eggs were first detected on days 5 and 6 , and excretion continued for 8 and 9 days in conventional and gnotobiotic mice, respectively.

In experiments with another group of germ-free and conventional animals, the mean number of worms recovered from the small intestine 7 days after infection was 3.6 times higher for gnotobiotic than for conventional mice. There was also a difference in faecal weight and worm length; female worms in conventional mice produced more eggs than those infecting gnotobiotic animals (Table 1).

Histopathological examination of the duodenal mucosa 


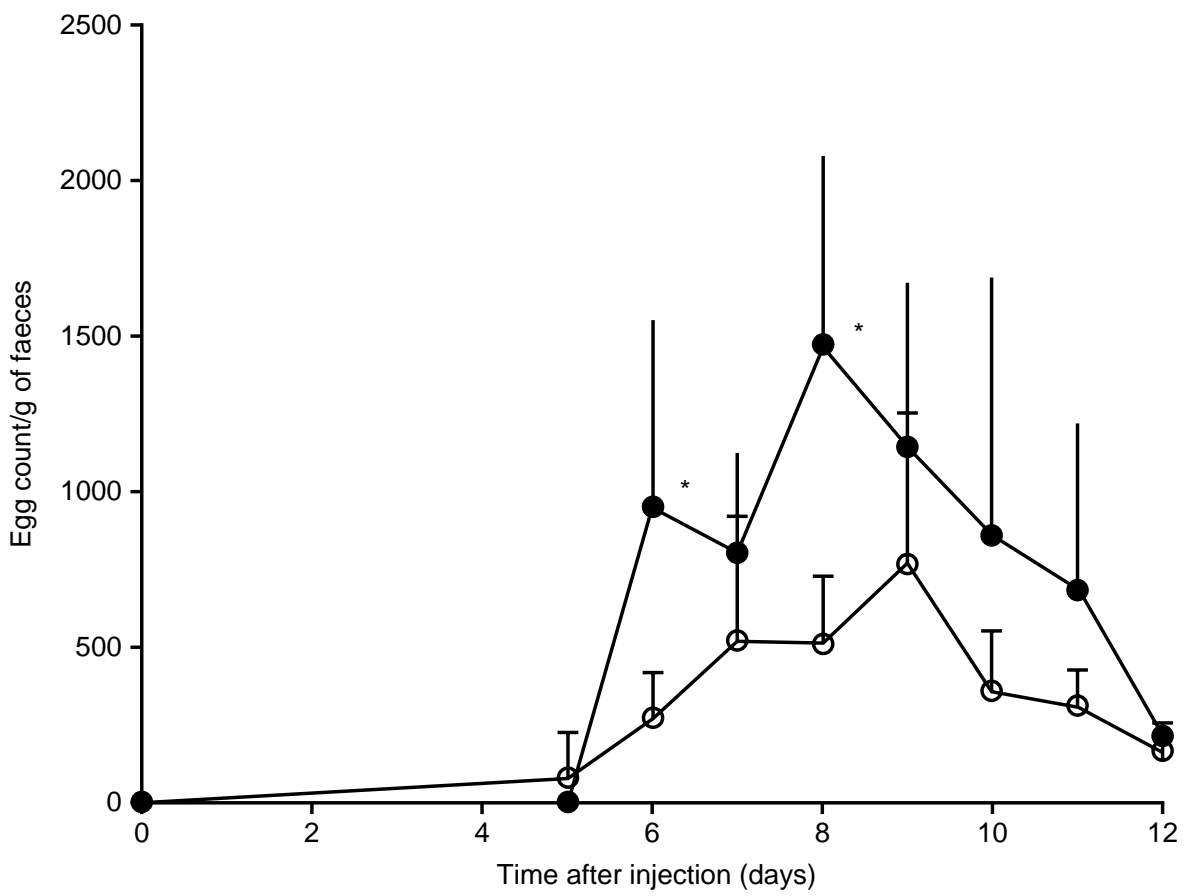

Fig. 1. Faecal egg excretion in germ-free $(\bullet)$ and conventional (O) NIH mice after infection with 500 axenic $S$. venezuelensis larvae (mean number of eggs/g of faeces; five mice/group). Vertical lines represent the SEM. * Significantly different from conventional mice $(\mathrm{p}<0.05)$.

Table 1. Faecal weight, faecal egg output, worm recovery, worm fecundity and worm length 7 days after infection of germ-free and conventional NIH mice with 500 axenic S. venezuelensis larvae (L3)

\begin{tabular}{lcc}
\hline & \multicolumn{2}{c}{ Mean (SEM) values } \\
\cline { 2 - 3 } Property & Conventional & Gnotobiotic \\
\hline Faecal weight $(\mathrm{g})$ & $0.018(0.004)$ & $0.034(0.005)$ \\
Faecal egg output (/g of faeces) & $3390(2088)$ & $5565(3685)$ \\
Worm recovery (/intestine) & $16.2(7.8)$ & $58.4(33.4)$ \\
Fecundity (eggs/worm) & $223(129)$ & $96(32)$ \\
Worm length (mm) & $1.79(0.39)$ & $2.05(0.39)$ \\
\hline
\end{tabular}

7 days after infection with $S$. venezuelensis showed more infiltration of the lamina propria, more evident goblet cells, more parasitic worms and a thicker mucosa in infected gnotobiotic mice. Villus hypotrophy appeared similar in gnotobiotic and conventional animals. Most worms were observed in the proximal portion of the small intestine in both types of mice.

\section{Discussion}

To examine the influence of the intestinal microbial flora on the course of strongyloides infection in germfree and conventional animals, the parasite must first be freed of micro-organisms. This was achieved with a combination of benzylpenicillin and ceftazidime after preliminary decontamination with sodium hypochlorite. Confirmation that the larvae were truly free from bacteria was obtained by inoculation of the deconta- minated larvae into gnotobiotic mice. This did not lead to loss of gnotobiotic status, although the digestive tract of the mice would be expected to efficiently amplify any contamination.

The infectivity of $S$. venezuelensis was higher in gnotobiotic than in conventional mice as judged by parasitological and histopathological examination. In both infected groups, adult worms were seen only in the proximal intestinal tract within the mucosa. Adult worms of $S$. stercoralis are similarly found in the duodenum and jejunum in human strongyloidiasis [9]. More worms were found in infected gnotobiotic mice than in conventional animals, and more severe histopathological changes were observed. In contrast to human infection with $S$. stercoralis, penetration of the worms in some gnotobiotic mice was associated with inflammatory foci and infiltration of the submucosa.

These results indicate that the bacterial intestinal ecosystem interferes with the course of infection with $S$. venezuelensis. This suggests that oral antibiotic treatment of an immunocompromised host might increase the pathogenicity of strongyloides by reducing the populations of intestinal bacteria. The mechanism of the effect might be direct antagonism or competition with the intestinal ecosystem, or both. Alternatively, stimulation of the local or systemic immune systems might be indirectly involved.

The study was supported by grants from Conselho Nacional de Desenvolvimento Científico e Tecnológico (CNPq) and Fundação de Amparo Ó Pesquisa do Estado de Minas Gerais (FAPEMIG). The 
authors thank Maria Gorete Barbosa Ribas, Ronilda Maria de Paula and Antônio Mesquita Vaz for valuable technical assistance.

\section{References}

1. Grove DI (ed). Strongyloidiasis: a major roundworm infection of man. London, Taylor and Francis. 1989

2. Baranski MC, de Silva AF, Kotaka PI, Gomes NR, Giovannoni $\mathrm{M}$, Telles JEQ. Tratamento da estrongiloidíase humana com novo anti-helmíntico, o Cambendazole, estudo duplo cego. [Treatment of human strongyloidiasis with a new anthelmintic, cambendazole. Double-blind study.] Rev Inst Med Trop São Paulo 1978; 20: 213-218.

3. Pawlowsky ZS. Intestinal helminthiases and human health: recent advances and future needs. $J$ Parasitol 1987; 17: 159-167.

4. Sato Y, Toma H. Strongyloides venezuelensis infections in mice. Int J Parasitol 1990; 20: 57-62.

5. Pleasants JR. Gnotobiotics. In: Melby EC, Altman NH (eds) Handbook of laboratory animal science. Cleveland, CRC Press. 1974: 119-174.

6. Morais RG. Contribuição para estudo do Strongyloides stercoralis e da estrongiloidíase no Brasil. Rev Serv Esp Saúde Públ 1948; 1: $507-524$.

7. Willis HH. A simple levitation method for the detection of hookworm ova. Med J Aust 1921; 2: 375-376.

8. Hoffman WA, Pons JA, Janer JL. El metodo de sedimentacion y concentracion en el diagnostico de la esquistosomiasis mansoni. [The sedimentation-concentration method in schistosomiasis mansoni.] Puerto Rico J Publ Hlth 1934; 9: 292-298.

9. Stemmerman GN. Strongyloidiasis in migrants. Pathological and clinical considerations. Gastroenterology 1967; 53: 59-70. 